\title{
Modulation of the Tissue Expression Pattern of Zebrafish CRP-Like Molecules Suggests a Relevant Antiviral Role in Fish Skin
}

\author{
Melissa Bello-Perez ${ }^{1}$, Mikolaj Adamek ${ }^{2}{ }^{\oplus}$, Julio Coll ${ }^{3}$, Antonio Figueras ${ }^{4} \oplus$, Beatriz Novoa ${ }^{4}$ and \\ Alberto Falco 1,*iD \\ 1 Institute of Research, Development, and Innovation in Healthcare Biotechnology in Elche (IDiBE), \\ Miguel Hernández University (UMH), 03202 Elche, Spain; melissa.bello@alu.umh.es \\ 2 Fish Disease Research Unit, Institute for Parasitology, University of Veterinary Medicine, \\ 30559 Hannover, Germany; mikolaj.adamek@tiho-hannover.de \\ 3 Department of Biotechnology, National Agricultural and Food Research and Technology Institute (INIA), \\ 28040 Madrid, Spain; juliocoll@inia.es \\ 4 Institute of Marine Research, Consejo Superior de Investigaciones Científicas (IIM-CSIC), 36208 Vigo, Spain; \\ antoniofigueras@iim.csic.es (A.F.); beatriznovoa@iim.csic.es (B.N.) \\ * Correspondence: alber.falco@umh.es; Tel.: +34-966-658-744
}

check for updates

Citation: Bello-Perez, M.; Adamek, M.; Coll, J.; Figueras, A.; Novoa, B.; Falco, A. Modulation of the Tissue Expression Pattern of Zebrafish CRP-Like Molecules Suggests a Relevant Antiviral Role in Fish Skin. Biology 2021, 10, 78. https://doi. org $/ 10.3390 /$ biology10020078

Academic Editor: Herman Spaink Received: 28 December 2020

Accepted: 19 January 2021

Published: 22 January 2021

Publisher's Note: MDPI stays neutral with regard to jurisdictional claims in published maps and institutional affiliations.

Copyright: (c) 2021 by the authors. Licensee MDPI, Basel, Switzerland. This article is an open access article distributed under the terms and conditions of the Creative Commons Attribution (CC BY) license (https:/ / creativecommons.org/licenses/by/ $4.0 /)$.
Simple Summary: The clinical use of the human short pentraxin C-reactive protein as a health biomarker is expanded worldwide. The acute increase of the serum levels of short pentraxins in response to bacterial infections is evolutionarily conserved, as are the main functions of pentraxins. Interestingly, fish orthologs have been found to increase similarly after bacterial and viral stimuli, thus becoming promising candidates for health biomarkers of both types of infection in this group of vertebrates. To preliminarily assess their adequacy for this application, zebrafish and a fish rhabdovirus were chosen as infection model systems for the analysis of the levels of gene expression of all short pentraxins in healthy and infected animals in a wide range of tissues. Because some significant increases were found in skin (a very suitable sampling source for testing purposes), further transcript analyses were carried out in this tissue. Due to the functional similarities between pentraxins and antibodies, it was also checked whether short pentraxins can compensate for the deficiencies in adaptive immunity by using mutant zebrafish lacking this system. In conclusion, the obtained results suggest that short pentraxins are highly reactant against viruses in skin and their overexpression seems to reflect a mechanism to compensate for the loss of adaptive immunity.

Abstract: Recent studies suggest that short pentraxins in fish might serve as biomarkers for not only bacterial infections, as in higher vertebrates including humans, but also for viral ones. These fish orthologs of mammalian short pentraxins are currently attracting interest because of their newly discovered antiviral activity. In the present work, the modulation of the gene expression of all zebrafish short pentraxins (CRP-like proteins, CRP1-7) was extensively analyzed by quantitative polymerase chain reaction. Initially, the tissue distribution of crp1-7 transcripts and how the transcripts varied in response to a bath infection with the spring viremia of carp virus, were determined. The expression of crp1-7 was widely distributed and generally increased after infection (mostly at 5 days post infection), except for crp1 (downregulated). Interestingly, several crp transcription levels significantly increased in skin. Further assays in mutant zebrafish of recombinant activation gene 1 (rag1) showed that all crps (except for crp2, downregulated) were already constitutively highly expressed in skin from rag1 knockouts and only increased moderately after viral infection. Similar results were obtained for most $m x$ isoforms (a reporter gene of the interferon response), suggesting a general overcompensation of the innate immunity in the absence of the adaptive one.

Keywords: short pentraxins; c-reactive protein; zebrafish; transcript expression; antiviral; SVCV; rag1 mutants; skin; mucosal immunity 


\section{Introduction}

Circulating pentraxins are considered pattern-recognition molecules that contribute to innate immunity by mainly facilitating the clearance of damaged cells and bacterial pathogens [1-4]. The representative forms of these molecules show an annular pentameric structural symmetry in humans [5]. Their monomers are characterized by the presence of a C-terminal domain of approximately 200 amino acid residues, containing the so-called "pentraxin signature", a conserved 8 amino acid residue sequence (HxCxS/TWxS) $[2,6,7]$. When an additional $\mathrm{N}$-terminal region is present, they are termed fusion or long pentraxins, and their prototype is pentraxin 3 (PTX3) [8]. In contrast, those soluble pentraxins consisting of just the C-terminal domain are termed classical or short pentraxins, and they include C-reactive protein (CRP) and serum-amyloid P component (SAP) [9].

The classification into CRPs and SAPs is mostly based on their differential ligand affinities in humans, although in other species this feature shows overlapping and even total reversion between the two groups [3,10-15]. Likewise, several oligomerization forms, other than pentameric, have also been identified across evolution, even in humans $[16,17]$. Nevertheless, because of shared homologous sequences corresponding to functionally important motifs and analogous molecular structures, fundamental activities associated with short pentraxins in humans are evolutionarily conserved [3,4,12-15]. One such activity is their role as reactive plasma proteins during the acute phase response (APR), an immediate and systemic physiological feedback of the innate immune system to trauma, injury, and infection [1-4]. In this regard, CRP is the predominant acute phase protein (APP) in most mammals and thus its clinical use as a health biomarker is common [1-4].

Although APRs are usually triggered during both bacterial and viral infections [18], increases of serum CRP levels in mammals are more characteristic of bacterial rather than viral infections $[1,18,19]$. In fish, short pentraxins are common ancestors of both mammalian CRP and SAP counterparts, which diverged very early in mammalian evolution after the separation of mammalian and avian lineages [20], and thus arose independently from a homologous differentiation in arthropods [7]. The existing studies analyzing the serum levels of fish short pentraxins (hereafter termed CRP-like proteins) show milder reactions than mammalian ones with similar response levels to bacterial and viral stimuli [21,22], which makes them potential biomarkers for both types of infection in fish. Interestingly, recent comparative studies of these ancestral orthologs have also revealed new interactions and activities such as affinity for different cholesterol metabolites, the modulation of autophagy, and antiviral activity [15,23-25].

In the present study, the transcript expression of all CRP-like protein (CRP1-7) encoding genes was analyzed extensively in zebrafish, which offers a great variety of scientific tools [26,27]. In addition to the determination of the tissue distribution of all crp transcripts and their modulation after infection with the spring viremia of carp virus (SVCV), they were also analyzed on the skin from zebrafish that are mutants of recombinant activation gene $1\left(\mathrm{rag}^{+/+}\right.$and $\left.\mathrm{rag} 1^{-/-}\right)$. The $\mathrm{rag}^{-/-}$mutants present a point mutation that generates a premature stop codon in the catalytic domain of this protein, at the endonuclease responsible for the $\mathrm{V}(\mathrm{D}) \mathrm{J}$ recombination [28]. This process results in functional macrophages, natural killer cells, and neutrophils and in a complete block of immunoglobulin gene assembly and T cell receptors (TCR) formation [29]. Moreover, it leads to the absence of adaptative immunity, providing a living platform to elucidate mechanisms of the innate immune responses [30]. Since CRPs have been previously referred to by other authors as ancient antibodies, because of their several analogous activities [2], this work aimed at investigating the behavior of these molecules in the absence of antibodies and at exploring their potential as health biomarkers of viral infections in fish.

\section{Materials and Methods}

\subsection{Cell Lines and Virus}

Epithelioma papulosum cyprinid (EPC) cells from fat-head minnow (Pimephales promelas) were purchased from the American Type Culture Collection (ATCC, Manassas, VI, USA, 
ref. no. CRL-2872). EPC cell monolayers were grown in Dutch-modified Roswell Park Memorial Institute (RPMI)-1640 culture medium (Sigma, St. Louis, MO, USA), supplemented with $10 \%$ fetal bovine serum (FBS) (Sigma), $2 \mathrm{mM}$ glutamine, $1 \mathrm{mM}$ sodium pyruvate, $50 \mu \mathrm{g} / \mathrm{mL}$ gentamicin, and $2 \mu \mathrm{g} / \mathrm{mL}$ of fungizone (Gibco BRL-Invitrogen, Carlsbad, CA, USA), at $28{ }^{\circ} \mathrm{C}$ in a $5 \% \mathrm{CO}_{2}$ atmosphere.

SVCV isolate 56/70 from carp (Cyprinus carpio) was replicated in EPC cells at $22{ }^{\circ} \mathrm{C}$ without $\mathrm{CO}_{2}$ supply and by using previously described cell culture media except for $2 \%$ FBS (infection media). After 7 days post-infection (dpi), infective supernatants were harvested, clarified by centrifugation at $4 \mathrm{~kg}$ and $4{ }^{\circ} \mathrm{C}$ for $30 \mathrm{~min}$, aliquoted, and stored at $-80^{\circ} \mathrm{C}$ until use. Virus titers in plaque forming units (pfu) were determined by the focus forming assay as described elsewhere [31].

\subsection{Animals}

The adult wild-type zebrafish (Danio rerio) were obtained by natural spawning from mating adults at one of the host institutions (Instituto de Investigaciones Marinas-CSIC, Vigo, Spain). Likewise, adult zebrafish that are mutants of recombinant activation gene 1 (rag $1^{+/+}$and $\mathrm{rag}^{-/-}$) were obtained at the University of Murcia (Murcia, Spain), and genotyped when they reached $\sim 1 \mathrm{~g}\left(\sim 6\right.$ months of age). Fish were maintained at $28^{\circ} \mathrm{C}$ in 30-L aquaria, following established protocols [26], and fed daily with commercial food (Vipan BioVip, Berlin, Germany). Before the infection experiments, fish were acclimatized to $22{ }^{\circ} \mathrm{C}$ for 2 weeks. Prior to methodological handling, fish were anaesthetized by immersion in $100 \mathrm{mg} / \mathrm{L}$ tricaine methanesulfonate (MS-222) (Sigma). End-point fish euthanasia was performed by overdosing with tricaine methanesulfonate $(500 \mathrm{mg} / \mathrm{L})$.

\subsection{Ethical Statement of Zebrafish Handling}

All experiments with zebrafish complied with the Spanish Law for Animal Experimentation (Royal Decree-Law, 53/2013) and the European Union Council Directive 2010/63/UE. Animal trial procedures were approved by the local government ethics committee on animal experimentation (Dirección General de Agricultura, Ganadería y Pesca, Generalitat Valenciana), the Project Evaluation Board of Miguel Hernández University (permit no. UMH.IBM.JFG.01.14), and the CSIC National Committee on Bioethics (permit no. ES360570202001/16/FUN01/PAT.05/tipoE/BNG).

\subsection{In Vivo Viral Infection}

For each infection experiment, zebrafish were exposed to $10^{4} \mathrm{ffu} / \mathrm{mL}$ of SVCV by bath immersion for $90 \mathrm{~min}$ at $22^{\circ} \mathrm{C}$ (optimal temperature for SVCV replication). Mock-infected zebrafish were incubated with equivalent volumes of cell culture medium in parallel experiments. Fish were then transferred to tanks with clean water and kept at $22{ }^{\circ} \mathrm{C}$ to allow for the progress of SVCV infection. Tissues were harvested at specific time points after infection for each experimental design. All tissues were dissected under a binocular loupe for transcript expression analysis.

For a general analysis of the tissue-specific transcription levels (tissue distribution assays) and their modulation in response to SVCV infection, four wild-type zebrafish were used for each condition; that is, four for the mock-infection, four for the 2-day infection, and four for the 5-day infection. Tissue samples from the mock-infected fish were collected at $2 \mathrm{dpi}$ and used to determine the basal (and reference) expression. The tissues collected comprised head kidney (HK), liver, skin, gills, gut, muscle, and spleen.

To analyze the modulation of the transcription levels in skin from $\mathrm{rag}^{+/+}$and $\mathrm{rag} \mathrm{1}^{-/-}$ zebrafish in response to SVCV, four individuals from each genotype were mock- and SVCVinfected. Skin samples from these fish were collected at 2 dpi to measure the early immune responses evoked by the virus entry and replication in one of its initial target tissues. 


\subsection{RNA Isolation, $c D N A$ Synthesis, and $q P C R$}

Total RNA was extracted by using EZNA HP Tissue RNA kits (Omega Bio-tek, Norcross, GA, USA) and subsequently treating the samples with DNase (Turbo DNA-free ${ }^{\mathrm{TM}}$ Kit, Ambion Inc., Austin, TX, USA) by following the manufacturer's instructions. RNA concentrations were estimated with a Nanodrop 1000 spectrophotometer (Thermo-fisher Scientific, Waltham, MA, USA). Isolated RNA samples were stored at $-80{ }^{\circ} \mathrm{C}$ until use.

For the synthesis of cDNA, $0.5 \mu \mathrm{g}$ of isolated RNA from each sample and the Moloney murine leukemia virus (M-MuLV) reverse transcriptase were used (Gibco BRL-Invitrogen), as previously described elsewhere [22].

qPCR was performed by using an ABI PRISM 7300 thermocycler (Applied Biosystems, Branchburg, NJ, USA). Reactions were conducted in 20- $\mu \mathrm{L}$-volume reactions comprising: $2 \mu \mathrm{L}$ of cDNA, $900 \mathrm{nM}$ of each corresponding forward and reverse primer (Sigma) (primer sequences are shown in Table S1), and $10 \mu \mathrm{L}$ of SYBR Green PCR master mix (Life Technologies, Paisley, UK). Non-template controls were added for each gene analysis. All reactions were performed using technical duplicates. Cycling conditions were an initial denaturing step $\left(10 \mathrm{~min}\right.$ at $95^{\circ} \mathrm{C}$ ), followed by 40 cycles comprising $1 \mathrm{~min}$ at $65^{\circ} \mathrm{C}$ and $1 \mathrm{~min}$ at $95^{\circ} \mathrm{C}$, and finally an extension step of $10 \mathrm{~min}$ at $65^{\circ} \mathrm{C}$. Melting curves were checked for inconstancies in each reaction. Cell and viral gene expression results were obtained and represented as relative transcription levels, by normalizing the expression level of each target gene to endogenous elongation factor 1- $\alpha$ (ef1a) levels by using a variation of

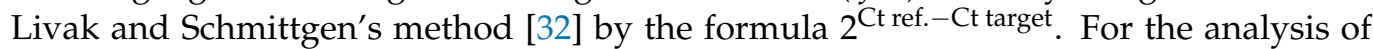
the transcriptional responses to SVCV infection, the data are represented as fold changes relative to the corresponding samples from mock-infected individuals (ef1a-normalized expression in samples from infected individuals/efla-normalized expression in samples from mock-infected individuals), and the data lower than 1-fold were inverted and represented as negative values to show downregulation.

\subsection{Statistical Analysis and Graphics}

Data are shown as mean and standard deviation (SD). Resulting datasets were subjected to the most appropriate statistical analysis depending on each particular experimental design. Significant differences were determined by one-way ANOVA and Tukey's multiple comparison (datasets in Section 3.1) or two-way ANOVA and Sidak's multiple comparison test (datasets in Sections 3.2 and 3.3). Prism v7 (Graphpad software, La Jolla, CA, USA) was used for creating the graphs and statistical analysis. $p<0.05, p<0.01$, and $p<0.001$ statistical differences with respect to control groups are indicated in each graph by the letters $a, b$, and c, respectively. Further details are specified accordingly in the figure captions.

\section{Results and Discussion}

\subsection{Broad Tissue Distribution of Zebrafish crp1-7 Expression}

All seven crp isoforms were expressed in all the tested tissues (HK, liver, skin, gills, gut, muscle, and spleen) from healthy adult zebrafish, albeit with quite different expression patterns (Figure 1). Among all the isoforms, crp3 and crp5 showed the most consistent and broad expression patterns, since the site of expression significantly affected the transcription levels reached by the others $(p<0.05)$. 

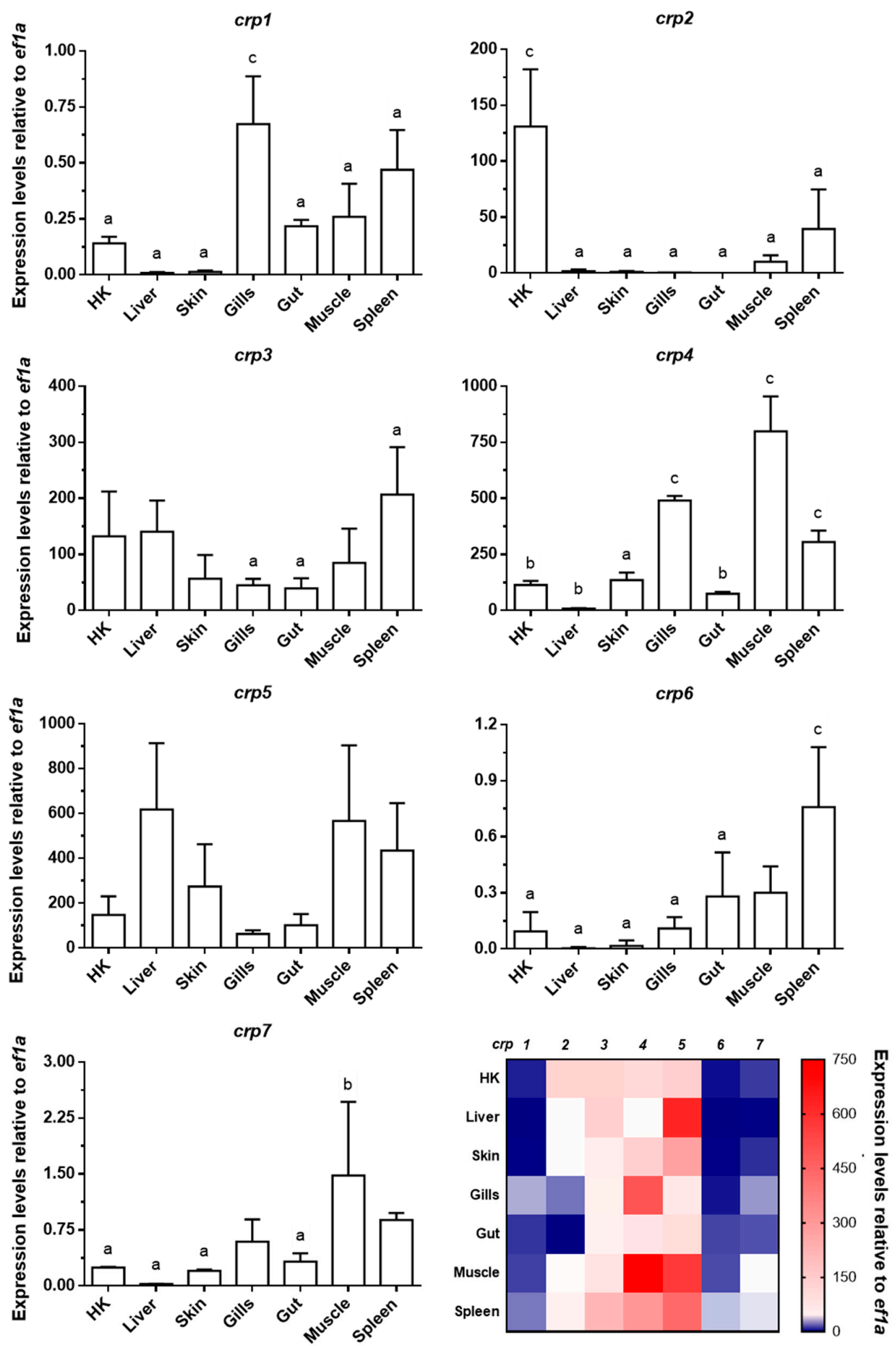

Figure 1. Gene expression analysis of $\operatorname{crp1-7}$ in tissues of healthy zebrafish. The expression of $\operatorname{crp1-7}$ was determined by RT-qPCR by using specific primers for each isoform (Table S1). ef1a mRNA was used as the endogenous control to normalize data, which are represented as the mean relative expression level $\times 10^{3} \pm \mathrm{SD}$ of four different individuals. Statistical differences ( $p<0.05$, one-way ANOVA) between tissues are represented by: a (different from up to 1-2 tissues), b (different from up to 3-4 tissues), and c (different from up to 5-6 tissues). Data in bar graphs are summarized in a final double gradient colormap (descending blue gradient for values from 0 to 1 and ascending red gradient from values from 1 to $\geq 750$ ). 
According to our results, the most pronounced expression level was found for crp 4 in muscle (799.95 \pm 155.24$)$, and the lowest one for crp1 in liver $(0.009 \pm 0.003)$. The spleen and muscle tissues appeared to be among the major basal expression sites for all crps. In general terms, our results confirm the broad extrahepatic expression of zebrafish crps, in line with previous observations in wild-type zebrafish [25], as well as in other fish species such as Salmo salar [33], Carassius auratus [34], Cyprinus carpio [35], Oplegnathus fasciatus [36], Plecoglossus altivelis [37], Sebastes schlegelii [38], and Cynoglossus semilaevis [39,40]. Interestingly, the skin also showed notable expression levels for some isoforms, particularly crp3-5. A few studies previously reported the expression of crps in skin from zebrafish [25], Cyprinus carpio [35,41], Oplegnathus fasciatus [36], and Sebastes schlegelii [38] and its presence in skin mucus from Gadus morhua [42], Raja kenojei [43], Cyclopterus lumpus [44], and Tilapia mossambica [45].

\subsection{Systemic Modulation of Zebrafish crp1-7 Expression Levels in Response to SVCV Infection}

The modulation of the crp1-7 expression profiles at each tissue in response to SVCV was also analyzed at 2 and 5 dpi by qPCR (Figure 2), and it revealed that both the infection stage and the tissue tested significantly altered the expression levels of each $\operatorname{crp}(p<0.001)$. As can be observed in Figure 2, SVCV infection resulted mostly in the upregulation of all crp isoforms, except for crp1, which was mostly downregulated. The highest increases occurred at $5 \mathrm{dpi}$, mainly for crp6 in liver ( $253 \pm 18$ folds), crp2 in gut ( $65 \pm 18$ folds), and $\operatorname{crp} 7$ in skin ( $62 \pm 8$ folds), matching with the highest viral loads, as observed from the expression pattern of the SVCV $n$ gene (Figure 2), which was similar to previously reported levels [46,47]. The SVCV infection levels at 2 dpi (Figure 2) were high in HK, spleen (the two most relevant lymphoid organs in fish [48]), and skin. In contrast, the lowest levels of SVCV $n$ expression were found in the liver at both time points. The modulation of the expression of certain crp genes in response to viral infections has been previously described, in some particular tissues, for zebrafish infected with SVCV [49] and viral hemorrhagic septicemia virus (VHSV) $[15,25]$, for Cyprinus carpio infected with cyprinid herpesvirus 3 (CyHV-3) [50] and injected with polyinosinic:polycytidylic acid (poly(I:C), which mimics viral infections) [22] and for Cynoglossus semilaevis [40] and Oplegnathus fasciatus [36] infected with red seabream iridovirus (RSIV), displaying a similar overall trend. However, the skin was not analyzed in any of those studies, and only one studied the gut, reporting increased levels of a carp crp isoform in this tissue in response to poly(I:C) [22].

In parallel, apart from the eventual but remarkable decrease in crp 2 transcripts in HK ( $-140 \pm 79$ folds), our results also revealed that SVCV infection downregulated the expression of crp1 in HK, gills, gut, and spleen (the lowest, -47-fold) at $5 \mathrm{dpi}$, which could be associated with the fact that CRP1 in zebrafish is the only exclusively intracellular isoform, since it lacks the signal peptide. The low participation of CRP1 in not only viral responses but also viral neutralization has been previoulsy described, suggesting that CRPs should be secreted to be efficient against viral infections [25].

The obtained results on the expression of crps also suggest that the liver is the major CRP-producing tissue in zebrafish in response to infection (Figure 2), as also occurs in mammals for CRP/SAP and other APPs when the APR is triggered $[1,18,51,52]$. Under this situation, the expression of CRP in mammals is principally induced in hepatocytes by the action of the cytokine interleukin-6 (IL-6), whose effect is boosted by interleukin-1 (IL1) [18,51-53]. A similar mechanism might be occurring in fish, as crp4 and crp5 are induced in zebrafish embryos microinjected with the il6 transgene [25] as is crp1a by recombinant cytokines il1b in primary HK cells from Salmo salar [33]. Furthermore, IL-6 has been found to increase in response to viral infections in both mammals [54-56] and fish $[57,58]$. In this vein, another parallelism to mammals is the observation of a wide extrahepatic expression of CRPs $[18,59]$. However, this event appears to be more relevant in fish as is inferred from the high basal (Figure 1) and SVCV-induced (Figure 2) levels of crp in the HK, gut, and, surprisingly, skin. 

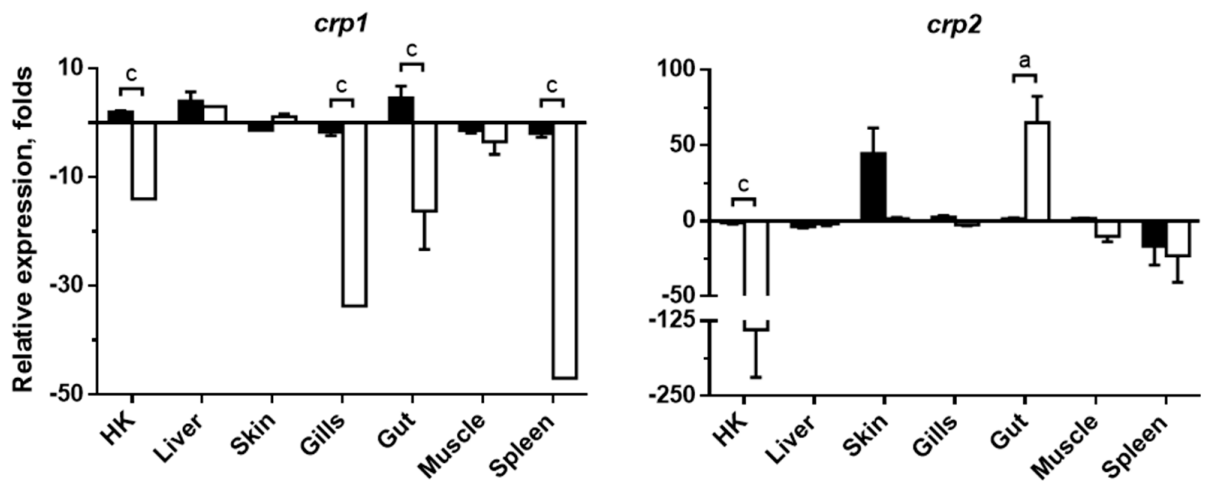

crp3
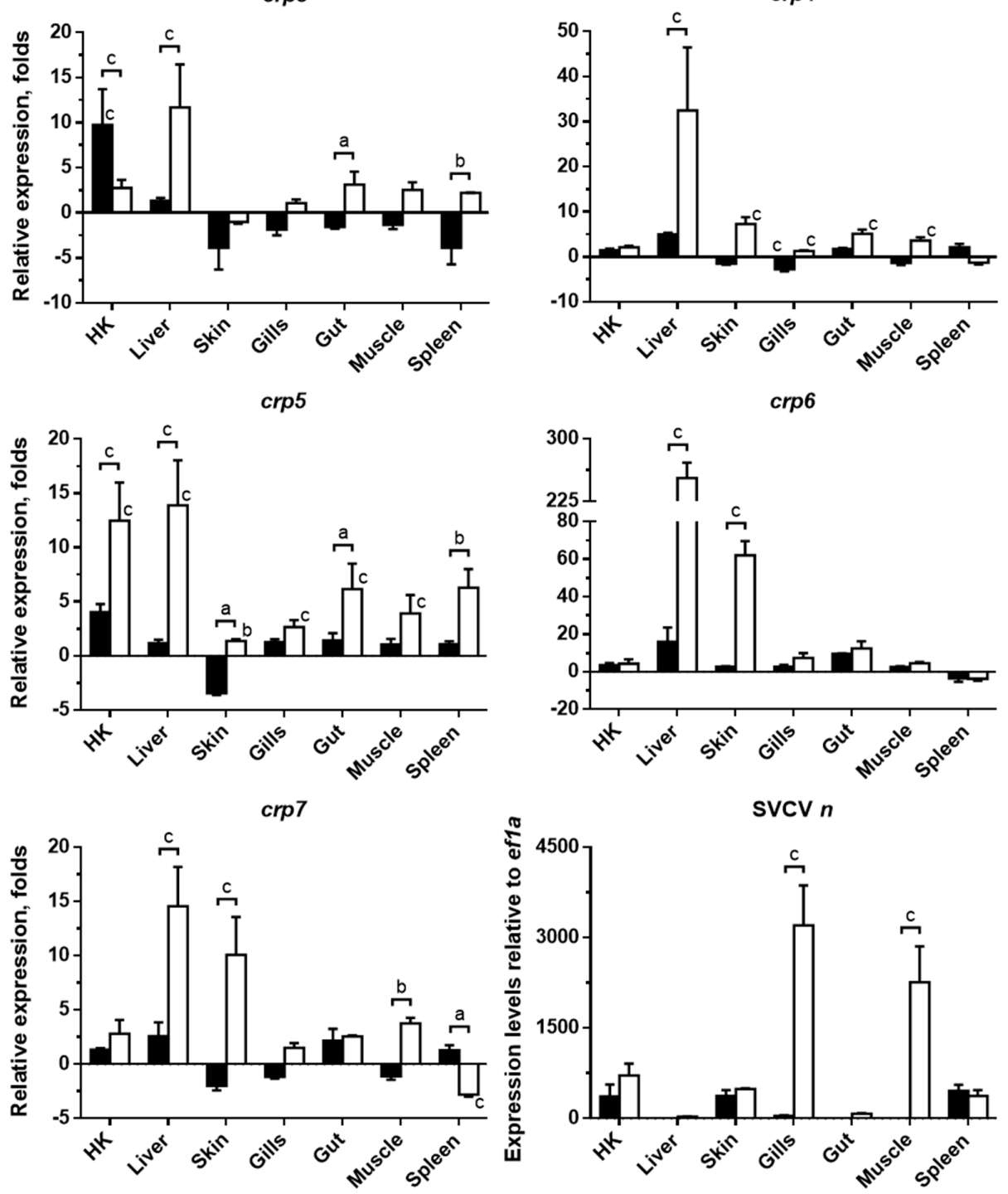

Figure 2. Expression modulation of crp1-7 in zebrafish tissues in response to spring viremia of carp virus (SVCV) infection. The transcription levels of $\operatorname{crp} 1-7$ and SVCV $n$ in tissues from SVCV-infected zebrafish at 2 and $5 \mathrm{dpi}$ (black and white bars, respectively) were quantified by RT-qPCR. ef1a mRNA was used as the endogenous control in all cases. crp1-7 transcription levels were also normalized to the values obtained from the corresponding samples in non-infected fish. Data are represented as the mean fold changes \pm SD for crps and as the mean relative expression level \pm SD for SVCV $n$ (four different individuals in all cases). Significant differences were determined by two-way ANOVA and Sidak's multiple comparison test. Statistical differences between the 2- and 5-dpi groups are represented by keys together with $a, b$, and $c$ letters on top. Statistical differences between the 2- or 5-dpi groups and the non-infected group are represented by $a$, $b$, and c letters just on top of the corresponding bars. $a, p \leq 0.05 ; b, p \leq 0.01 ; c, p \leq 0.001$. 


\subsection{CRPs Are Constitutively Overexpressed in Skin in the Absence of Adaptive Immunity}

The modulation of the expression of some zebrafish crps in response to SVCV in skin, which had not been described before, attracted our attention. On the one hand, the skin is not considered a major lymphoid $[48,60]$ nor APR-related $[18,51]$ tissue. On the other hand, the skin is one of the preferential entry sites of rhabdovirus in fish [61,62], which explains its early and notable response. In addition, the skin is the largest immunologically active organ in fish and is a type of secondary lymphoid tissue called diffuse mucosa-associated lymphoid tissue (MALT), which is not only endowed with strong innate immune activity, but also with relevant adaptive immune properties [60,63-65].

In order to further characterize this effect in the skin of zebrafish and to explore a potential involvement of the adaptive immune system, a comparative study of the expression changes of crps in skin in response to SVCV infection was performed in rag1 mutants. In this experiment we analyzed the basal and SVCV-induced levels of crps in $\mathrm{rag}^{\mathrm{H}^{++}}$and $\mathrm{rag} 1^{-/-}$mutant zebrafish. At this point, it is worth mentioning that wild-type zebrafish (previous experiments) and the $\mathrm{rag}^{+/+}$zebrafish (following experiments) may differ at some level in the expression of certain genes due to the fact that the former ones include not only homo, but also heterozygous rag1 individuals $\left(\mathrm{rag} 1^{+/+}\right.$and $\left.\mathrm{rag} 1^{+/-}\right)$, which may be affected by transcriptional compensatory mechanisms as they are partially deficient in the generation of a mature adaptive immune response [28].

The results (Figure 3 ) show that basal expression levels of rag1-/- zebrafish were higher for $\operatorname{crp} 1,3$, and 5, and lower for just $\operatorname{crp} 2$, in comparison to that of $r a g 1^{+/+}$zebrafish. After viral challenge, the expression levels of all crps, except for crp2 (which continued to be downregulated), appeared to increase in $\mathrm{rag} 1^{+/+}$fish, although only the $\mathrm{crp} 7$ transcription levels were found to be significantly upregulated in this experiment. Regarding rag ${ }^{+/+}$and rag $1^{-1-}$ infected groups of zebrafish, expression differences between them were similar to those found at basal conditions, i.e., crp1, 4, 5, and 7 expression levels were upregulated in $\mathrm{rag}^{-/}$zebrafish, while no differences were detected among their viral loads. When comparing the effect of the SVCV infection on the rag $1^{-/-}$group, only the expression levels of crp4 (from 36.25 to 66.90) and crp7 (13.40 to 46.76) were modulated, suggesting that most crp basal expression in this group might be already close to maximum levels.

The modulation of the transcription levels of $m x$, an interferon (IFN) stimulated gene (ISG) often used as a marker of the activation of the type I IFN response, was also analyzed in these samples, resulting in similar results as those previously observed for crp genes (Supplementary Figure S1). Thus, the determination of the expression levels of mxa-g zebrafish isoforms confirmed that the IFN response to the viral infection was triggered in skin from experimental fish, and that the basal expression of most $m x$ isoforms in rag $1^{-/-}$ fish had also reached similar levels to those found after SVCV infection. This observation is in agreement with previous evidence indicating that basal immunological status is elevated in $\mathrm{rag}^{-1-}$ mutants and extends to skin, as well as the parallel modulation of multigene families associated to the antiviral response [66]. In the case of crp genes, such compensatory effects might be due not only to their recently described antiviral activity $[23-25,40]$ but also their evolutionary-conserved antibody-like activities [15,67-69]. In addition, the upregulation of this type of genes in $\mathrm{rag}^{-1-}$ mutants has been associated with epigenetic reprogramming [70], similar to the underlying mechanisms regulating innate trained immunity [71,72], and apparently also occurring in the crp genes in zebrafish [73]. 

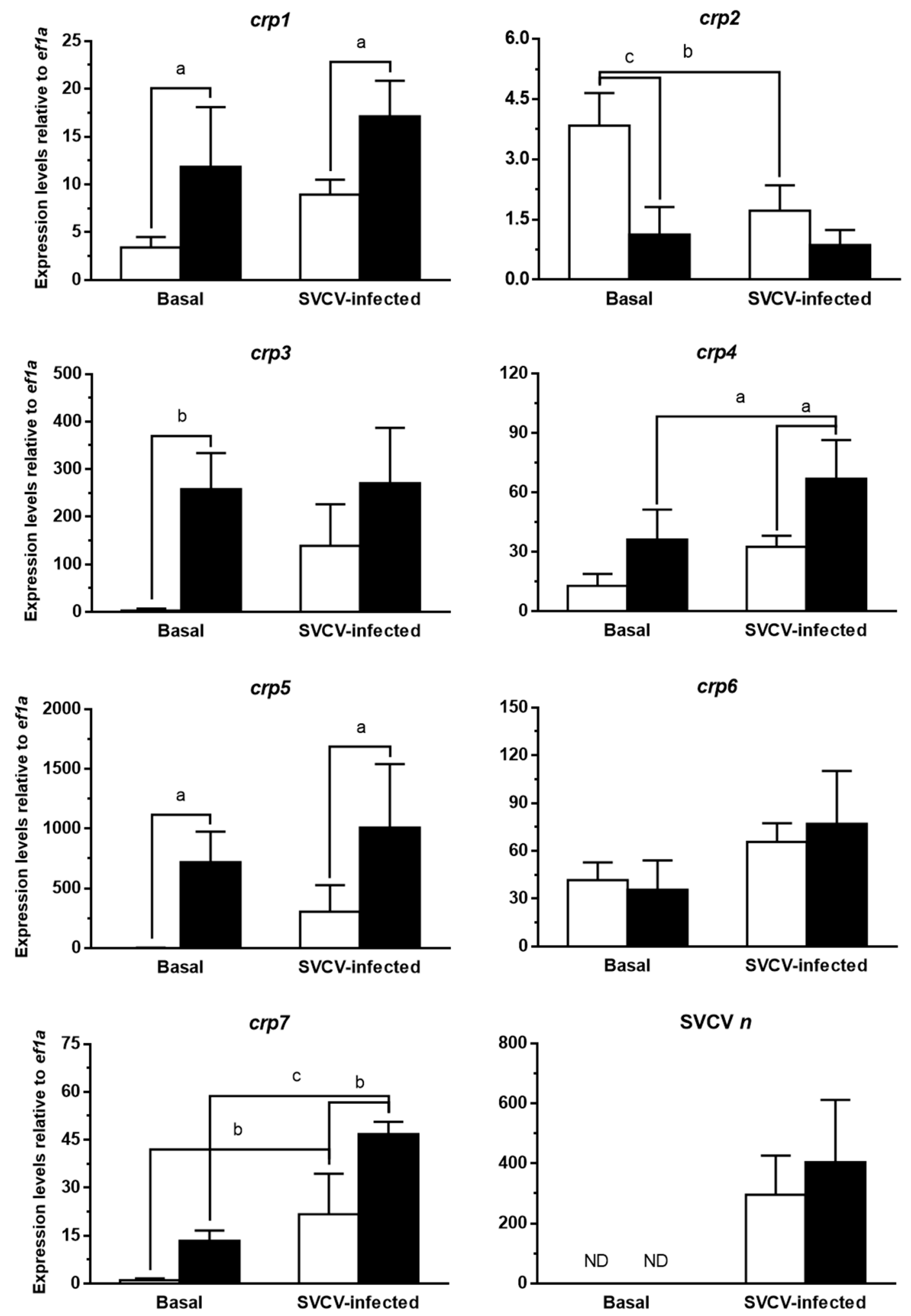

Figure 3. Expression modulation of crp1-7 in skin from rag mutant zebrafish in response to SVCV infection. The transcription levels of $\mathrm{crp} 1-7$ and SVCV $n$ were quantified by RT-qPCR in the skin of $\mathrm{rag}^{+/+}$(white bars) and $\mathrm{rag}^{-/-}$(black bars) mutant zebrafish at 2 dpi with SVCV. ef1a mRNA was used as the endogenous control to normalize data, which are represented as the mean relative expression level $\left(\times 10^{3}\right.$ for $\left.\operatorname{crps}\right) \pm \mathrm{SD}$ of four different individuals. Significant differences were determined by two-way ANOVAs and Sidak's multiple comparison test. Statistical differences between the experimental groups are represented by keys together with $\mathrm{a}, \mathrm{b}$, and cletters on top. $\mathrm{a}, p \leq 0.05 ; \mathrm{b}, p \leq 0.01 ; \mathrm{c}, p \leq 0.001$; ND, not detected. 


\section{Conclusions}

The present study aimed at contributing to the current knowledge on fish short pentraxins by describing extensively the tissue distribution of the transcript expression of all seven zebrafish crp genes and their modulation in each tissue, especially skin, in response to infection with SVCV. Thus, all crps were found to be constitutively expressed in all tested tissues (i.e., HK, liver, skin, gills, gut, muscle, and spleen). In general terms, crp 4 and crp5 presented the highest levels of expression, and gills, muscle, and skin were the major sites of expression. In skin, relatively high values were found for crp 4 and crp5. After SVCV infection, all crps were mostly upregulated, except for crp1, which was mainly downregulated. Predominantly, the highest increases occurred at 5 dpi and in the liver. Significant upregulations were also found in skin for crp5-7. Additional experiments were completed to further characterize the reactivity of crps to SVCV in skin; they included the use of rag1 mutants to additionally explore the response of crps levels at a both the mucosal and SVCV entry sites in the absence of adaptive immunity. In comparison to rag ${ }^{+/+}$control zebrafish, rag $1^{-/-}$mutants showed elevated basal levels of most crps but unaltered crp6 and 7 levels and the downregulated crp2. Furthermore, SVCV infection increased just moderately the expression of most crp genes, except for crp 2 and crp6, which remained unaltered. The analysis of the transcript expression of all $m x$ isoforms on these samples indicates a generalized elevation in skin of the basal status of the innate immune system in fish without adaptive immunity. Altogether, the results obtained confirm the reactivity of crps to viral infections and suggest the skin, and by extension the skin mucus, as a promising sampling source for biomarker testing purposes.

Supplementary Materials: The following are available online at https:/ /www.mdpi.com/2079-7 737/10/2/78/s1, Table S1: qPCR primer sequences for zebrafish genes and SVCV $n$, Figure S1: Expression modulation of mxa-g in skin from rag mutant zebrafish in response to SVCV infection.

Author Contributions: Conceptualization, A.F. (Alberto Falco); methodology, M.B.-P., M.A., and A.F. (Alberto Falco); software, M.B.-P., M.A., and A.F. (Alberto Falco); validation, M.B.-P. and A.F. (Alberto Falco); formal analysis, A.F. (Antonio Figueras) and A.F. (Alberto Falco); investigation, M.B.P., J.C., B.N., A.F. (Antonio Figueras), and A.F. (Alberto Falco); resources, J.C., B.N., A.F. (Antonio Figueras), and A.F. (Alberto Falco); data curation, A.F. (Antonio Figueras) and A.F. (Alberto Falco); writing—original draft preparation, A.F. (Alberto Falco); writing—review and editing, M.B.-P., M.A., J.C., B.N. A.F. (Antonio Figueras), and A.F. (Alberto Falco); visualization, M.B.-P. and A.F. (Antonio Figueras); supervision, A.F. (Antonio Figueras); project administration, B.N., A.F. (Antonio Figueras), and A.F. (Alberto Falco); funding acquisition, J.C. B.N., A.F. (Antonio Figueras), and A.F. (Alberto Falco). All authors have read and agreed to the published version of the manuscript.

Funding: This research was funded by FEDER/Spanish Ministry of Science, Innovation and Universities - State Agency of Research, grant number RTI2018-101969-J-I00 and BIO2017-82851-C3-1R; Xunta de Galicia (GAIN), grant number IN607B 2019/01, and Generalitat Valenciana and Fondo Social Europeo (FSE) 2014-2020, grant number ACIF/2016/207.

Institutional Review Board Statement: All experiments with zebrafish complied with the Spanish Law for Animal Experi-mentation (Royal Decree-Law, 53/2013) and the European Union Council Directive 2010/63/UE. Animal trial procedures were approved by the local government ethics com-mittee on animal experimentation (Dirección General de Agricultura, Ganadería y Pesca, Generalitat Valenciana), the Project Evaluation Board of Miguel Hernández University (permit no. UMH.IBM.JFG.01.14), and the CSIC National Committee on Bioethics (permit no. ES360570202001/16/ FUN01/PAT.05/tipoE/BNG).

Informed Consent Statement: Not applicable.

Data Availability Statement: The data presented in this study are available on request from the corresponding author.

Acknowledgments: We thank Victoriano Mulero (University of Murcia) for kindly providing the zebrafish lines.

Conflicts of Interest: The authors declare no conflict of interest. 


\section{References}

1. Pepys, M.B.; Hirschfield, G.M. C-reactive protein: A critical update. J. Clin. Investig. 2003, 111, 1805-1812. [CrossRef] [PubMed]

2. Garlanda, C.; Bottazzi, B.; Bastone, A.; Mantovani, A. Pentraxins at the crossroads between innate immunity, inflammation, matrix deposition, and female fertility. Annu. Rev. Immunol. 2005, 23, 337-366. [CrossRef] [PubMed]

3. Armstrong, P.B. Comparative biology of the pentraxin protein family: Evolutionarily conserved component of innate immune system. Int. Rev. Cell Mol. Biol. 2015, 316, 1-47. [PubMed]

4. Pathak, A.; Agrawal, A. Evolution of c-reactive protein. Front. Immunol. 2019, 10. [CrossRef]

5. Shrive, A.K.; Cheetham, G.M.; Holden, D.; Myles, D.A.; Turnell, W.G.; Volanakis, J.E.; Pepys, M.B.; Bloomer, A.C.; Greenhough, T.J. Three dimensional structure of human c-reactive protein. Nat. Struct. Biol. 1996, 3, 346-354. [CrossRef]

6. Nguyen, N.Y.; Suzuki, A.; Boykins, R.A.; Liu, T.Y. The amino acid sequence of limulus c-reactive protein. Evidence of polymorphism. J. Biol. Chem. 1986, 261, 10456-10465. [CrossRef]

7. Tharia, H.A.; Shrive, A.K.; Mills, J.D.; Arme, C.; Williams, G.T.; Greenhough, T.J. Complete cdna sequence of sap-like pentraxin from limulus polyphemus: Implications for pentraxin evolution. J. Mol. Biol. 2002, 316, 583-597. [CrossRef]

8. Introna, M.; Breviario, F.; d'Aniello, E.M.; Golay, J.; Dejana, E.; Mantovani, A. Il-1 inducible genes in human umbilical vein endothelial cells. Eur. Heart J. 1993, 14 (Suppl. K), 78-81.

9. Pepys, M.B.; Baltz, M.L. Acute phase proteins with special reference to c-reactive protein and related proteins (pentaxins) and serum amyloid a protein. Adv. Immunol. 1983, 34, 141-212.

10. Amatayakul-Chantler, S.; Dwek, R.A.; Tennent, G.A.; Pepys, M.B.; Rademacher, T.W. Molecular characterization of limulus polyphemus c-reactive protein. Ii. Asparagine-linked oligosaccharides. Eur. J. Biochem. 1993, 214, 99-110. [CrossRef]

11. Pepys, M.B.; Baltz, M.; Gomer, K.; Davies, A.J.; Doenhoff, M. Serum amyloid p-component is an acute-phase reactant in the mouse. Nature 1979, 278, 259-261. [CrossRef] [PubMed]

12. Schwalbe, R.A.; Dahlback, B.; Coe, J.E.; Nelsestuen, G.L. Pentraxin family of proteins interact specifically with phosphorylcholine and/or phosphorylethanolamine. Biochemistry 1992, 31, 4907-4915. [CrossRef] [PubMed]

13. Coe, J.E.; Ross, M.J. Hamster female protein, a sex-limited pentraxin, is a constituent of syrian hamster amyloid. J. Clin. Investig. 1985, 76, 66-74. [CrossRef] [PubMed]

14. Srinivasan, N.; White, H.E.; Emsley, J.; Wood, S.P.; Pepys, M.B.; Blundell, T.L. Comparative analyses of pentraxins: Implications for protomer assembly and ligand binding. Structure 1994, 2, 1017-1027. [CrossRef]

15. Bello-Perez, M.; Falco, A.; Medina, R.; Encinar, J.A.; Novoa, B.; Perez, L.; Estepa, A.; Coll, J. Structure and functionalities of the human c-reactive protein compared to the zebrafish multigene family of c-reactive-like proteins. Dev. Comp. Immunol. 2017, 69, 33-40. [CrossRef]

16. Shrive, A.K.; Metcalfe, A.M.; Cartwright, J.R.; Greenhough, T.J. C-reactive protein and sap-like pentraxin are both present in limulus polyphemus haemolymph: Crystal structure of limulus sap. J. Mol. Biol. 1999, 290, 997-1008. [CrossRef]

17. Chen, R.; Qi, J.; Yuan, H.; Wu, Y.; Hu, W.; Xia, C. Crystal structures for short-chain pentraxin from zebrafish demonstrate a cyclic trimer with new recognition and effector faces. J. Struct. Biol. 2015, 189, 259-268. [CrossRef]

18. Cray, C. Acute phase proteins in animals. Prog. Mol. Biol. Transl. Sci. 2012, 105, 113-150.

19. Ansar, W.; Ghosh, S. C-reactive protein and the biology of disease. Immunol. Res. 2013, 56, 131-142. [CrossRef]

20. Rubio, N.; Sharp, P.M.; Rits, M.; Zahedi, K.; Whitehead, A.S. Structure, expression, and evolution of guinea pig serum amyloid p component and c-reactive protein. J. Biochem. 1993, 113, 277-284. [CrossRef]

21. MacCarthy, E.M.; Burns, I.; Irnazarow, I.; Polwart, A.; Greenhough, T.J.; Shrive, A.K.; Hoole, D. Serum crp-like protein profile in common carp cyprinus carpio challenged with aeromonas hydrophila and escherichia coli lipopolysaccharide. Dev. Comp. Immunol. 2008, 32, 1281-1289. [CrossRef] [PubMed]

22. Pionnier, N.; Falco, A.; Miest, J.J.; Shrive, A.K.; Hoole, D. Feeding common carp cyprinus carpio with beta-glucan supplemented diet stimulates c-reactive protein and complement immune acute phase responses following pamps injection. Fish Shellfish Immunol. 2014, 39, 285-295. [CrossRef] [PubMed]

23. Bello-Perez, M.; Pereiro, P.; Coll, J.; Novoa, B.; Perez, L.; Falco, A. Zebrafish c-reactive protein isoforms inhibit svcv replication by blocking autophagy through interactions with cell membrane cholesterol. Sci. Rep. 2020, 10, 1-18. [CrossRef]

24. Bello-Perez, M.; Falco, A.; Novoa, B.; Perez, L.; Coll, J. Hydroxycholesterol binds and enhances the anti-viral activities of zebrafish monomeric c-reactive protein isoforms. PLoS ONE 2019, 14, e0201509. [CrossRef]

25. Bello-Perez, M.; Falco, A.; Medina-Gali, R.; Pereiro, P.; Encinar, J.A.; Novoa, B.; Perez, L.; Coll, J. Neutralization of viral infectivity by zebrafish c-reactive protein isoforms. Mol. Immunol. 2017, 91, 145-155. [CrossRef] [PubMed]

26. Westerfield, M. The Zebrafish Book: A Guide for the Laboratory Use of Zebrafish (Brachydanio rerio); University of Oregon Press: Eugene, OR, USA, 1995.

27. MacRae, C.A.; Peterson, R.T. Zebrafish as tools for drug discovery. Nat. Rev. Drug Discov. 2015, 14, 721-731. [CrossRef] [PubMed]

28. Valenzuela-Muñoz, V.; Pereiro, P.; Álvarez-Rodríguez, M.; Gallardo-Escárate, C.; Figueras, A.; Novoa, B. Comparative modulation of lncrnas in wild-type and rag1-heterozygous mutant zebrafish exposed to immune challenge with spring viraemia of carp virus (svcv). Sci. Rep. 2019, 9, 1-13. [CrossRef]

29. Petrie-Hanson, L.; Hohn, C.; Hanson, L. Characterization of rag 1 mutant zebrafish leukocytes. BMC Immunol. 2009, 10, 1-8. [CrossRef] 
30. Hohn, C.; Petrie-Hanson, L. Rag1 ${ }^{-/-}$mutant zebrafish demonstrate specific protection following bacterial re-exposure. PLoS ONE 2012, 7, e44451. [CrossRef]

31. Espin-Palazon, R.; Martinez-Lopez, A.; Roca, F.J.; Lopez-Munoz, A.; Tyrkalska, S.D.; Candel, S.; Garcia-Moreno, D.; Falco, A.; Meseguer, J.; Estepa, A. Tnf $\alpha$ impairs rhabdoviral clearance by inhibiting the host autophagic antiviral response. PLoS Pathog. 2016, 12, e1005699. [CrossRef]

32. Livak, K.J.; Schmittgen, T.D. Analysis of relative gene expression data using real-time quantitative pcr and the 2(-delta delta c(t)) method. Methods 2001, 25, 402-408. [CrossRef]

33. Lee, P.; Bird, S.; Zou, J.; Martin, S. Phylogeny and expression analysis of c-reactive protein (crp) and serum amyloid-p (sap) like genes reveal two distinct groups in fish. Fish Shellfish Immunol. 2017, 65, 42-51. [CrossRef] [PubMed]

34. Kovacevic, N.; Hagen, M.O.; Xie, J.; Belosevic, M. The analysis of the acute phase response during the course of trypanosoma carassii infection in the goldfish (Carassius auratus L.). Dev. Comp. Immunol. 2015, 53, 112-122. [CrossRef]

35. Falco, A.; Cartwright, J.R.; Wiegertjes, G.F.; Hoole, D. Molecular characterization and expression analysis of two new c-reactive protein genes from common carp (Cyprinus carpio). Dev. Comp. Immunol. 2012, 37, 127-138. [CrossRef] [PubMed]

36. Choi, K.-M.; Shim, S.H.; An, C.M.; Nam, B.-H.; Jeong, J.-M.; Kim, J.-W.; Park, C.-I. Functional characterisation and expression analysis of recombinant serum amyloid p isoform 1 (rbsap1) from rock bream (Oplegnathus fasciatus). Fish Shellfish Immunol. 2015, 45, 277-285. [CrossRef] [PubMed]

37. Shi, Y.-H.; Chen, K.; Ma, W.-J.; Chen, J. Ayu c-reactive protein/serum amyloid p agglutinates bacteria and inhibits complementmediated opsonophagocytosis by monocytes/macrophages. Fish Shellfish Immunol. 2018, 76, 58-67. [CrossRef]

38. Elvitigala, D.A.S.; Wan, Q.; Kim, H.C.; Lee, J. Identification of a c-reactive protein like homologue from black rockfish (Sebastes schlegelii) evidencing its potent anti-microbial properties at molecular level. Dev. Comp. Immunol. 2015, 53, 169-178. [CrossRef]

39. Li, M.-f.; Chen, C.; Li, J.; Sun, L. The c-reactive protein of tongue sole cynoglossus semilaevis is an acute phase protein that interacts with bacterial pathogens and stimulates the antibacterial activity of peripheral blood leukocytes. Fish Shellfish Immunol. 2013, 34, 623-631. [CrossRef]

40. Wang, T.; Sun, L. Cssap, a teleost serum amyloid p component, interacts with bacteria, promotes phagocytosis, and enhances host resistance against bacterial and viral infection. Dev. Comp. Immunol. 2016, 55, 12-20. [CrossRef]

41. Pietrzak, E.; Mazurkiewicz, J.; Slawinska, A. Innate immune responses of skin mucosa in common carp (Cyprinus carpio) fed a diet supplemented with galactooligosaccharides. Animals 2020, 10, 438. [CrossRef]

42. Magnadóttir, B.; Hayes, P.; Gísladóttir, B.; Bragason, B.P.; Hristova, M.; Nicholas, A.P.; Guðmundsdóttir, S.; Lange, S. Pentraxins crp-i and crp-ii are post-translationally deiminated and differ in tissue specificity in cod (Gadus morhua L.) ontogeny. Dev. Comp. Immunol. 2018, 87, 1-11. [CrossRef] [PubMed]

43. Tsutsui, S.; Yamaguchi, M.; Hirasawa, A.; Nakamura, O.; Watanabe, T. Common skate (raja kenojei) secretes pentraxin into the cutaneous secretion: The first skin mucus lectin in cartilaginous fish. J. Biochem. 2009, 146, 295-306. [CrossRef] [PubMed]

44. Patel, D.M.; Brinchmann, M.F. Skin mucus proteins of lumpsucker (Cyclopterus lumpus). Biochem. Biophys. Rep. 2017, 9, 217-225. [CrossRef] [PubMed]

45. Ramos, F.; Smith, A.C. The c-reactive protein (crp) test for the detection of early disease in fishes. Aquaculture 1978, 14, 261-266. [CrossRef]

46. Shao, L.; Xiao, Y.; He, Z.; Gao, L. An n-targeting real-time pcr strategy for the accurate detection of spring viremia of carp virus. J. Virol. Methods 2016, 229, 27-34. [CrossRef] [PubMed]

47. Wang, Y.; Kuang, M.; Lu, Y.; Lin, L.; Liu, X. Characterization and biological function analysis of the trim47 gene from common carp (Cyprinus carpio). Gene 2017, 627, 188-193. [CrossRef] [PubMed]

48. Uribe, C.; Folch, H.; Enríquez, R.; Moran, G. Innate and adaptive immunity in teleost fish: A review. Vet. Med. 2011, 56, 486-503. [CrossRef]

49. Encinas, P.; Garcia-Valtanen, P.; Chinchilla, B.; Gomez-Casado, E.; Estepa, A.; Coll, J. Identification of multipath genes differentially expressed in pathway-targeted microarrays in zebrafish infected and surviving spring viremia carp virus (svcv) suggest preventive drug candidates. PLOS ONE 2013, 8, e73553. [CrossRef]

50. Pionnier, N.; Adamek, M.; Miest, J.J.; Harris, S.J.; Matras, M.; Rakus, K.Ł.; Irnazarow, I.; Hoole, D. C-reactive protein and complement as acute phase reactants in common carp cyprinus carpio during cyhv-3 infection. Dis. Aquat. Org. 2014, 109, 187-199. [CrossRef]

51. Gruys, E.; Toussaint, M.; Niewold, T.; Koopmans, S. Acute phase reaction and acute phase proteins. J. Zhejiang Univ. Sci. B 2005, 6, 1045. [CrossRef]

52. Mantovani, A.; Garlanda, C.; Doni, A.; Bottazzi, B. Pentraxins in innate immunity: From c-reactive protein to the long pentraxin ptx3. J. Clin. Immunol. 2008, 28, 1-13. [CrossRef] [PubMed]

53. Kushner, I.; Jiang, S.-L.; Zhang, D.; Lozanski, G.; Samols, D. Do post-transcriptional mechanisms participate in induction of c-reactive protein and serum amyloid a by il-6 and il-1? Ann. N. Y. Acad. Sci. 1995, 762, 102-107. [CrossRef] [PubMed]

54. Paludan, S.R. Requirements for the induction of interleukin-6 by herpes simplex virus-infected leukocytes. J. Virol. 2001, 75, 8008-8015. [CrossRef] [PubMed]

55. Wang, J.; Wang, Q.; Han, T.; Li, Y.-K.; Zhu, S.-L.; Ao, F.; Feng, J.; Jing, M.-Z.; Wang, L.; Ye, L.-B. Soluble interleukin-6 receptor is elevated during influenza a virus infection and mediates the il-6 and il-32 inflammatory cytokine burst. Cell. Mol. Immunol. 2015, 12, 633-644. [CrossRef] [PubMed] 
56. Xia, C.; Liu, Y.; Chen, Z.; Zheng, M. Involvement of interleukin 6 in hepatitis b viral infection. Cell. Physiol. Biochem. 2015, 37, 677-686. [CrossRef] [PubMed]

57. Øvergård, A.-C.; Nerland, A.H.; Fiksdal, I.U.; Patel, S. Atlantic halibut experimentally infected with nodavirus shows increased levels of t-cell marker and ifn $\gamma$ transcripts. Dev. Comp. Immunol. 2012, 37, 139-150. [CrossRef] [PubMed]

58. Wei, X.; Li, X.Z.; Zheng, X.; Jia, P.; Wang, J.; Yang, X.; Yu, L.; Shi, X.; Tong, G.; Liu, H. Toll-like receptors and interferon associated immune factors responses to spring viraemia of carp virus infection in common carp (Cyprinus carpio). Fish Shellfish Immunol. 2016, 55, 568-576. [CrossRef]

59. Black, S.; Kushner, I.; Samols, D. C-reactive protein. J. Biol. Chem. 2004, 279, 48487-48490. [CrossRef]

60. Lazado, C.C.; Caipang, C.M.A. Mucosal immunity and probiotics in fish. Fish Shellfish Immunol. 2014, 39, 78-89. [CrossRef]

61. Harmache, A.; LeBerre, M.; Droineau, S.; Giovannini, M.; Brémont, M. Bioluminescence imaging of live infected salmonids reveals that the fin bases are the major portal of entry for novirhabdovirus. J. Virol. 2006, 80, 3655-3659. [CrossRef]

62. Bearzotti, M.; Delmas, B.; Lamoureux, A.; Loustau, A.-M.; Chilmonczyk, S.; Bremont, M. Fish rhabdovirus cell entry is mediated by fibronectin. J. Virol. 1999, 73, 7703-7709. [CrossRef] [PubMed]

63. Esteban, M.Á.; Cerezuela, R. Fish mucosal immunity: Skin. In Mucosal Health in Aquaculture; Elsevier: Amsterdam, The Netherlands, 2015; pp. 67-92.

64. Salinas, I. The mucosal immune system of teleost fish. Biology 2015, 4, 525-539. [CrossRef] [PubMed]

65. Xu, Z.; Takizawa, F.; Casadei, E.; Shibasaki, Y.; Ding, Y.; Sauters, T.J.; Yu, Y.; Salinas, I.; Sunyer, J.O. Specialization of mucosal immunoglobulins in pathogen control and microbiota homeostasis occurred early in vertebrate evolution. Sci. Immunol. 2020, 5 . [CrossRef] [PubMed]

66. García-Valtanen, P.; Martínez-López, A.; López-Muñoz, A.; Bello-Perez, M.; Medina-Gali, R.M.; Ortega-Villaizán, M.d.M.; Varela, M.; Figueras, A.; Mulero, V.; Novoa, B. Zebra fish lacking adaptive immunity acquire an antiviral alert state characterized by upregulated gene expression of apoptosis, multigene families, and interferon-related genes. Front. Immunol. $2017,8,121$. [PubMed]

67. Agrawal, A.; Singh, P.P.; Bottazzi, B.; Garlanda, C.; Mantovani, A. Pattern recognition by pentraxins. In Target Pattern Recognition in Innate Immunity; Springer: Berlin/Heidelberg, Germany, 2009; pp. 98-116.

68. Chorny, A.; Casas-Recasens, S.; Sintes, J.; Shan, M.; Polentarutti, N.; García-Escudero, R.; Walland, A.C.; Yeiser, J.R.; Cassis, L.; Carrillo, J. The soluble pattern recognition receptor ptx3 links humoral innate and adaptive immune responses by helping marginal zone b cells. J. Exp. Med. 2016, 213, 2167-2185. [CrossRef]

69. Bottazzi, B.; Doni, A.; Garlanda, C.; Mantovani, A. An integrated view of humoral innate immunity: Pentraxins as a paradigm. Annu. Rev. Immunol. 2009, 28, 157-183. [CrossRef]

70. Novoa, B.; Pereiro, P.; López-Muñoz, A.; Varela, M.; Forn-Cuní, G.; Anchelin, M.; Dios, S.; Romero, A.; Martinez-López, A.; Medina-Gali, R.M. Rag1 immunodeficiency-induced early aging and senescence in zebrafish are dependent on chronic inflammation and oxidative stress. Aging Cell 2019, 18, e13020. [CrossRef]

71. Netea, M.G.; Joosten, L.A. Master and commander: Epigenetic regulation of macrophages. Cell Res. 2016, 26, 145-146. [CrossRef]

72. Quintin, J.; Saeed, S.; Martens, J.H.; Giamarellos-Bourboulis, E.J.; Ifrim, D.C.; Logie, C.; Jacobs, L.; Jansen, T.; Kullberg, B.-J.; Wijmenga, C. Candida albicans infection affords protection against reinfection via functional reprogramming of monocytes. Cell Host Microbe 2012, 12, 223-232. [CrossRef]

73. Medina-Gali, R.; Bello-Perez, M.; Martinez-Lopez, A.; Falco, A.; Ortega-Villaizan, M.M.; Encinar, J.A.; Novoa, B.; Coll, J.; Perez, L. Chromatin immunoprecipitation and high throughput sequencing of svcv-infected zebrafish reveals novel epigenetic histone methylation patterns involved in antiviral immune response. Fish. Shellfish Immunol. 2018, 82, 514-521. [CrossRef] 